\title{
Physical characterization of spray-dried milk powders and their agglomerates with the addition of carob, cinnamon, and ginger powders
}

\author{
Keçiboynuzu, tarçın ve zencefil tozu içeren püskürtmeli kurutucuda \\ kurutulmuş süt tozlarının ve aglomeratlarının fiziksel karakterizasyonu
}

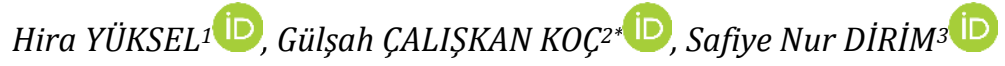 \\ 1,3Food Engineering Department, Engineering Faculty, Ege University, İzmir, Turkey. \\ hirayuksel@gmail.com, nur.dirim@ege.edu.tr
}

2Department of Gastronomy and Culinary Arts, Tourism Faculty, Alanya Hamdullah Emin Paşa University, Antalya, Turkey. gulsah_caliskan86@hotmail.com

Received/Geliş Tarihi: 27.06.2018, Accepted/Kabul Tarihi: 09.04.2019

doi: $10.5505 /$ pajes.2019.56798

* Corresponding author/Yazışlan Yazar Research Article/Araștırma Makalesi

\begin{abstract}
The scope of the study is to determine the influence of the addition of different amounts of carob (CP), cinnamon (CNP), and ginger (GP) powders and fluidized bed agglomeration process on the moisture content, water activity and powder properties of milk powders as well as powder yield and the energy consumption of the drying and agglomeration operations. CP, CNP, and GP were directly added to whole milk at different concentrations (1-8 \% by weight), mixed for $30 \mathrm{~min}$ and filtered by crude filter paper. Then, the filtrate was spray dried at the inlet and outlet air temperatures of 160 and $80{ }^{\circ} \mathrm{C}$ respectively. The powder yield ranged between 55.57-67.07\% for milk powder with CP (MPCP), 45.48-61.04\% for milk powder with CNP (MPCNP), and 42.42-46.93\% for milk powder with GP (MPGP). The addition of the powders decreased the total drying time and energy consumption of the drying process $(p<0.05)$. The agglomeration process was performed at $1.8 \mathrm{~m} / \mathrm{s}$, and $80^{\circ} \mathrm{C}$ for $15 \mathrm{~min}$. During this process, water (1:0.1 weight: weight, water: powder) was added to powders as a binder. Agglomerates have higher moisture content $(3.45-4.60 \%$, wet basis) and water activity (0.171-0.257) values compared to corresponding powders. The solubility times of powders decreased with the increasing amount of ingredients. Higher bulk $\left(200-259 \mathrm{~kg} / \mathrm{m}^{3}\right)$ and tapped $\left(339-400 \mathrm{~kg} / \mathrm{m}^{3}\right)$ density values were obtained from MPGP compared to other powders. Agglomeration process improved the flow properties of milk powders and increased the bulk and tapped density values. The long solubility times of milk powders (194-244.5 s) reduced to 10-50 s by means of the applied agglomeration process.
\end{abstract}

Keywords: Milk powder, Agglomerate, Spray drying, Fluidized bed agglomeration, Powder properties

\section{Introduction}

The consumption of milk is very high due to the content of the necessary nutrients as proteins, fats, carbohydrates minerals and vitamins. Since milk is highly perishable, fermentation (fermented beverages, yogurt, cheese etc.), evaporation (concentrated), pasteurization, sterilization (Ultra High Temperature), and drying (powder) processes can be used to prolong the shelf life and consumption areas of milk [1]. The conversion of milk into the powder form increases the shelf life in a suitable packaging material and extends the storage period (around 1 year) even at ambient temperatures without loss of quality. Milk powders are more convenient to use while transporting, packaging and in processes with a case of ease handling and to be used in food recipes than milk itself. The consumption areas of the milk powders are; reconstitution, the $\underline{\text { Öz }}$

Bu çalıșmanın amacl; farklı miktarlarda keçiboynuzu (CP), tarçın (CNP) ve zencefil (GP) tozu katkısının ve akışkan yatak aglomerasyon işleminin süt tozlarının nem, su aktivitesi ve toz özellikleri, toz verimi ve kurutma ve aglomerasyon işlemlerinin enerji tüketimi üzerindeki etkisinin belirlenmesidir. Farklı konsantrasyonlarda (\%1-8 ağırlıkça) $C P, C N P$ ve GP doğrudan tam yağll inek sütüne ilave edilmis ve $30 \mathrm{dk}$. süre ile karıștırılarak kaba filtre kağıdından süzülmüștür. Elde edilen filtrat $160 / 80{ }^{\circ} \mathrm{C}$ hava giriș/çıkıș sıcaklığında pilot ölçekli püskürtmeli kurutucuda kurutulmuștur. Toz ürün verimi CP içeren süt tozlarında (MPCP) \%55.57-67.07, CNP içeren süt tozlarında (MPCNP) \%45.48-61.04 ve GP içeren süt tozlarinda (MPGP) ise \%42.42-46.93 arasında değişmiştir. Aromaların ilavesi, kuruma süresi ve enerji tüketimini azaltmıștır (p<0.05). Aglomerasyon ișlemi $1.8 \mathrm{~m} / \mathrm{s}$, ve $80{ }^{\circ} \mathrm{C}^{\prime} \mathrm{de} 15 \mathrm{dk}$. süre ile gerçekleştirilmiștir. Bu işlem süresince, su (1:0.1 ağırlık: ağırlık, su: toz) bağlayıcı olarak toz ürünlere ilave edilmiştir. Aglomeratların nem içeriği (\%3.45-4.60, yaş bazlı) ve su aktivitesi değerleri (0.171-0.257) süt tozlarına klyasla daha yüksek bulunmuștur. Toz ürünlerin çözünürlük süreleri ilave edilen aroma maddesine bağlı olarak azalmıştır. Yüksek yığın (200-259 kg/m³) ve sıkıștırılmıs yığın (339-400 kg/m33) yoğunluğu değerleri MPGP'den elde edilmiştir. Aglomerasyon işlemi, süt tozlarının akabilirlik özelliklerini; yığın ve sıkıștırılmış yığın yoğunluğu değerlerini arttırmıştır. Süt tozlarının uzun çözünürlük süreleri (194-244.5 s) uygulanan aglomerasyon işlemiyle 10-50 s'ye düşürülmüştür.

Anahtar kelimeler: Süt tozu, Aglomerat, Püskürtmeli kurutma, Akıșkan yatak aglomerasyon, Toz özellikler

use in the composition of "value-added foods" as cookies, baby meals, coffee products and processed meat [1],[2]. World production of skim milk powder showed an increase of $2.8 \%$ in 2016 to 2.3 million tons according to the report of the Food and Agriculture Organization of the United Nations. The European Union was the largest producer with annual production of 700000 tons per year [3].

Drum drying was commonly used for the milk powder production until 1960. However, now due to the high efficiency of the spray drying process, almost all powders are obtained with this method. Spray drying technique allows liquid products to be converted into a powder product by atomizing the liquid into the drying chamber [4]. The obtained particle size change between $10-100 \mu \mathrm{m}$ for spray-dried powders. This small particle size leads to some difficulties such as deterioration in the reconstitution properties of the powder 
products and separation from other materials during processing and transportation. Agglomeration can be applied to spray-dried powders in order to solve these problems [5]. With the application of agglomeration easily dispersing instant products as coffee, milk or cacao products to be dissolved quickly in water and milk can be obtained [6]. In addition, the agglomeration process increases efficiency and production intensity, improve working conditions, and reduces raw material loss. During the agglomeration process, particles bond together and improve their handling and reconstitution properties like dispersibility, solubility etc. [7]. The application of the agglomeration process is divided into two major groups; wet and dry agglomeration. Wet agglomeration process is superior to dry process due to the fact that, it provides better control of particle homogeneity and bulk and tapped density values [8]. This process contains different methods such as fluidized bed, drum agglomeration, high shear agglomeration etc. Among them, the fluidized bed agglomeration is commonly used than the others. The agglomerates with high porosity and homogeneity are obtained by the fluidized bed agglomeration method and they can be more easily wetted in the liquid than the spray-dried powder product, can sink more easily through the liquid surface, and can be dispersed with less mixing and dissolve more easily in the liquid [5]. Although they have very limited utilization in the food industry, dry agglomeration methods are performed between the rolls which a continuous process where the product can be agglomerated at a low cost [9],[10] and this process is easy and environmental friendly [11].

Carob has high soluble sugar, dietary fiber, phenolic compounds, antioxidant activity etc. Carob is used as the raw material for the production of locust bean gum, cacao substitute in dietetic foods, cereal supplement that can be used for celiac patients and as animal feed [12]-[14]. Cinnamon also commonly used as flavoring agent in several products as bakeries (cookies, desserts, etc.), breakfast cereals, alcoholic beverages, milk products (latte, yogurt, etc.), spices, confectioneries, and chewing gum. In addition to flavoring application, cinnamon also has several properties as, antimicrobial and antioxidant activity, controller action in glucose intolerance and diabetes together with its flavoring action [15]. Ginger also has several biological activities such as antioxidant, antimicrobial etc. bringing it a potential use against a variety of health problems [16]. Ginger is commonly used as a seasoning and flavoring agent in Asian cuisine, and flavoring for cookies, crackers, cakes, ginger ale, beer, and bread.

At the same time, the spices carob, cinnamon, and ginger have some well-proven health beneficial properties and generally used with milk or milk products such as desserts etc. But, as our knowledge, there is no study related to the addition of the carob, cinnamon, and ginger powders to the whole milk. As a consequence, the goals of the present study were to produce the instant whole milk powder (WMP) with carob, cinnamon, and ginger powders and to improve the reconstitution properties of obtained milk powders by the wet agglomeration process. The objective of this study is to examine the effect of carob, cinnamon, and ginger powders on the physical and the powder properties of the spray dried milk powders, powder and agglomeration yield and total energy consumption of the drying and agglomeration processes.

\section{Material and method}

The commercial sterilized whole (WM) milk was purchased from KIPA, Izmir, Turkey and carob, cinnamon, and ginger powders were bought from Değirmen Ticaret, İzmir, Turkey.

\subsection{Methods}

\subsubsection{Preparation of the whole milk with carob, cinnamon, and ginger powders extracts}

Carob, cinnamon, and ginger powders were added to the whole milk at different concentrations $(1,2,4$, and $8 \% \mathrm{w}: \mathrm{w}$, weight:weight), mixed for 30 minutes by a magnetic stirrer (Wise Stir, MSH-20A, Korea) and filtered by crude filter paper (Whatman No: 1).

\subsubsection{Spray drying of the milk}

A pilot scale spray dryer equipped with a rotary atomizer (Mobile Minor Niro-Atomizer, Denmark) was used for drying experiments. The samples (whole milk and whole milks with different amounts of CP, CNP, and GP) were atomized by a rotary atomizer into a vertical co-current drying chamber (0.87x1.2 $\mathrm{m}$ diameter $\mathrm{x}$ height). The inlet and outlet temperatures, air flow rate and atomization pressure were set as $160{ }^{\circ} \mathrm{C}, 80{ }^{\circ} \mathrm{C}, 1.54 \mathrm{~m}^{3} / \mathrm{min}$ and $392 \mathrm{kPa}$ respectively. The feed flow rate is set to provide the desired output temperature. The milk was fed the spray dryer at room temperature. The milk powders were cooled to room temperature and packed with commercial multilayer packaging material suitable for heat sealing and kept at room temperature in the desiccator to be used in the analyses.

\subsubsection{Agglomeration of the milk powders}

The agglomeration process was carried out by using the modified fluid bed dryer (Sherwood Scientific, UK) in the Department of Food Engineering at Ege University. The agglomeration was carried with $10 \mathrm{~g}$ of whole milk and milk powders containing $2 \%$ carob, cinnamon, and ginger powders with a nozzle $(0.1 \mathrm{~mm}$ diameter $)$ at $1.8 \mathrm{~m} / \mathrm{s}$ air flow rate, at $80{ }^{\circ} \mathrm{C}$ air temperature, and $0.6 \mathrm{ml} / \mathrm{min}$ flow rate of water for 15 minutes. The distilled water was used as a binder in a ratio of 1:10, water: powder, (w:w).

\subsubsection{Calculation of the energy efficiency of the processes}

The device (Makil M310.2218, Turkey) that measures the total energy consumption of the process was used to measure the total energy consumption for spray drying and agglomeration processes. Based on the measured energy consumption and drying data the following terms as the specific moisture extraction rate (SMER), the moisture extraction rate (MER) and specific energy consumption (SEC) values of the spray drying process were calculated for the energy efficiency of the spray dryer [17],[18].

\subsubsection{Determination of the powder production and agglomeration yields (\%)}

The powder yield (\%) was calculated as the ratio of the amount of obtained milk powder to the total soluble solid content (TSSC) of the milk. The TSSC values were measured with Worldbest, Fg 108, Turkey refractometer. Similarly, the agglomerate yield was calculated as the ratio of the amount of milk agglomerates (remaining on top of the screen with $250 \mu \mathrm{m}$ mesh size) to the amount of milk powder (w:w, \%) as a percentage. 


\subsubsection{Determination of moisture content, water activity, and color values}

The moisture content ( $\%$ wet basis, wb) of the samples were determined according to AOAC [19]. The water activity $\left(\mathrm{a}_{\mathrm{w}}\right)$, and color values $\left(\mathrm{L}^{*}, \mathrm{a}^{*}\right.$, and $\mathrm{b}^{*}$ ) of the samples (milk powders and agglomerates) were determined according to by using a Testo-AG 400, Germany water activity measurement device and Konica Minolta CR-400, Japan colorimeter. The total color change values $\Delta E=\sqrt{\left(\Delta L^{* 2}+\Delta a^{* 2}+\Delta b^{* 2}\right)}$ of agglomerated milk powders with respect to corresponding milk powders were calculated.

\subsubsection{Powder properties}

The average solubility time, bulk and tapped densities, and dispersibility values of the CP, CNP, GP, milk powders, and the agglomerated milk powders were determined according to Goula and Adamopoulos [20] and Jinapong et al [21], respectively. The Carr Index (CI) and Hausner Ratio (HR) values used for the evaluation of flowability and cohesiveness properties. The the Carr Index (CI) and Hausner Ratio (HR) were calculated using the values of the bulk density and tapped density values ( $t_{\text {apped }}$ ) [22],[23]. The hygroscopicity values were determined by using the method of Cai and Croke [24]. Screen analysis was performed by using a vibratory sieve shaker (Jettiest, Turkey) to determine the size distribution of the agglomerated milk powders. The aperture sizes of sieves were $212 \mu \mathrm{m}, 300 \mu \mathrm{m}, 500 \mu \mathrm{m}, 710 \mu \mathrm{m}, 1 \mathrm{~mm}$, and $2 \mathrm{~mm}$. The agglomerated milk powders were put on the series of sieves and shaken for $5 \mathrm{~min}$. Then, the weight of the samples at each sieve was weighed and evaluated as in Eq. (1).

$D_{s}=\frac{1}{\sum x_{i} d_{p i}}$

Ds $=$ volume-surface mean particle diameter $(\mathrm{mm})$

$\mathrm{Xi}=$ mass fraction

Dpi $=$ average particle diameter (arithmetic mean of largest and smallest diameters) (mm)

\subsubsection{Statistical evaluation}

Experimental results tested with 95\% confidence interval ANOVA using SPSS 16.0 (SPSS Inc., Chicago, IL, USA). The Duncan multiple range test $(\alpha=0.05)$ was used to determine the difference between the experimental results. The drying and agglomeration experiments were replicated and all the analyses were triplicated.

\section{Results and discussion}

There are several kinds of flavored milk such as cocoa, strawberry, banana etc. finding space in the markets. In the literature, there is a study related to the addition of the mixed fruit flavor to the concentrated goat milk where the aim was to prevent the goaty flavor in the product [25]. Considering the gap in this area this study was performed. In the preliminary experiments, it was observed that complete dissolution of the carob, cinnamon, and ginger powders and a stable form of the mixture could not be obtained. For this reason, the powders were directly added to whole milk and after filtration, the dissolved part of the powders and milk were dried together as a kind of encapsulation process. By this way, the soluble powders as a combination of milk powder and one of the powders of carob, cinnamon or ginger were obtained. These powders can be used in any formulation of food materials and to determine their properties this study has been conducted.

\subsection{The results of the moisture content, water activity, bulk density and tapped density measurements of carob, cinnamon, and ginger powders}

The moisture content, water activity and powder properties of the original $\mathrm{CP}, \mathrm{CNP}$, and GP were also performed due to the determination of the effect of them on the properties of milk powders. The results of the physical and powder properties and the color values of CP, CNP, and GP are given in Table 1 and Figure 1, respectively. Depending on the data given in Table 1, it can be stated that, the highest moisture content, a*, b*, bulk, and tapped density values were observed for cinnamon powder, the highest water activity and dispersibility values were observed for carob powder, and the highest $L^{*}$, flowability, and cohesiveness values were observed for ginger powder.

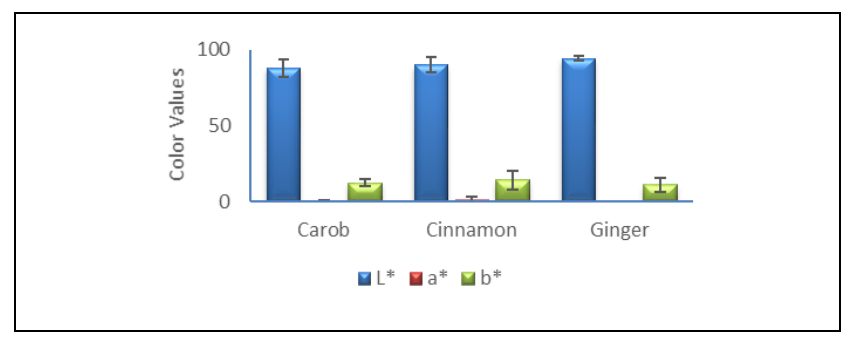

Figure 1: The color values of carob, cinnamon, and ginger powders.

In the literature, the moisture content values of the carob, cinnamon, and ginger powders were found to be as $11.7 \%$ (water activity $=0.45,[26]$ ), $10.6 \%$ [27], and 4.9\%-5.6\% [28], respectively. The reason for the differences can be explained by the differences between the drying methods, storage conditions or the variety of plants. The CP, CNP, and GP did not dissolve in the distilled water completely. For this reason, the solubility times of the CP, CNP, and GP cannot be determined. The large variation in the physical and powder properties of the powders was a good contribution to the study. In this way, their effect on the obtained milk powders and the agglomerates were easily discussed.

Table 1: The moisture content, water activity, bulk density and tapped density values of carob, cinnamon, and ginger powders.

\begin{tabular}{|c|c|c|c|}
\hline Analysis & Carob Powder (CP) & Cinnamon Powder (CNP) & Ginger Powder (GP) \\
\hline Moisture Content $(\%, w b)$ & $7.74 \pm 0.21^{\mathrm{a}}$ & $8.80 \pm 0.83^{\mathrm{b}}$ & $8.46 \pm 0.16^{\mathrm{b}}$ \\
\hline Water Activity & $0.534 \pm 0.01^{\mathrm{c}}$ & $0.521 \pm 0.03^{\mathrm{b}}$ & $0.500 \pm 0.02^{\mathrm{a}}$ \\
\hline Bulk Density $\left(\mathrm{kg} / \mathrm{m}^{3}\right)$ & $443.51 \pm 27.91^{b}$ & $564.29 \pm 97.61^{\mathrm{c}}$ & $301.21 \pm 4.55^{\mathrm{a}}$ \\
\hline Tapped Density $\left(\mathrm{kg} / \mathrm{m}^{3}\right)$ & $548.41 \pm 1.58^{\mathrm{b}}$ & $623.68 \pm 107.00^{c}$ & $499.47 \pm 5.03^{a}$ \\
\hline Hausner & $1.24 \pm 0.07^{\mathrm{b}}$ & $1.11 \pm 0.00^{\mathrm{a}}(\mathrm{Low})$ & $1.66 \pm 0.01^{\mathrm{c}}$ \\
\hline Ratio & (Intermediate) & & (High) \\
\hline Carr Index & $19.14 \pm 4.86^{\mathrm{b}}$ (Good) & $9.52 \pm 0.00^{\text {a }}$ (Very good $)$ & $39.69 \pm 0.30 \mathrm{c}(\mathrm{Bad})$ \\
\hline Dispersibility (\%) & $65.43 \pm 2.06^{c}$ & $23.52 \pm 2.23^{\mathrm{a}}$ & $54.59 \pm 3.52^{\mathrm{b}}$ \\
\hline
\end{tabular}

a-d: Show a significant difference between the samples (in the same row, $\mathrm{P}<0.05$ ). 


\subsection{The energy consumption values for the spray dryer and fluidized bed dryer and the percentage yield values of milk powders and agglomerates (\%)}

The energy consumptions of the spray dryer and the modified fluidized bed dryer used for agglomeration process were measured by an energy measurement device and ranged between $1.2529 \mathrm{kWh}$ (WMP with 8\% GP) $-3.0372 \mathrm{kWh}$ (WMP with 1\% CNP) and $0.1170 \mathrm{kWh}$ (MPCNP) $-0.1900 \mathrm{kWh}$ (WMP), respectively. The drying time of milk powders and energy consumption of spray dryer are given in Table 2. For the low concentrations of CP, CNP and GP high energy consumption was observed (Table 2). The total energy consumption of spray dryer and yield for WMP were found to be as $0.75 \pm 0.05 \mathrm{kWh}$ and $31.50 \mathrm{~min}$, respectively. Although the same amount of milk (500 g) was used for the drying experiments, the increase in the amounts of the powders resulted in different drying times as CP (33.96-18.49 $\mathrm{min})$, CNP (22.80-45.48 $\mathrm{min})$ and GP (19.77-29.42 min). The TSSC of the WMP was found to be as $11.0 \pm 0.2$ and TSSC of milk with carob, cinnamon or ginger powders are given in Table 3. In the literature, the acceptable process efficiency value was reported as more than 50\% recovery in the cyclone by Bhandari et al. [29]. For this reason, it can be stated that acceptable process efficiency values were observed during drying. The whole milk powder yield was determined to be as $48.06 \pm 2.41 \%$ and the MPCP, MPCNP and MPGP yields (\%) are given in Table 3.
In all the drying experiments, in order to prevent the heat effect, the samples were used without any pre-concentration process. Most of the milk powders were collected from the collector and a little amount was recovered in the cyclone and drying chamber. The results showed that an increase in the TSSC of the feed generally resulted in a significant increase in the efficiency except for milk powder with $8 \% \mathrm{CP}, \mathrm{CNP}$ and GP $(\mathrm{P}<0.05)$. Fang and Bhandari [30], also reported that the main reasons of powder losses as, stuck particles on the wall of the dryer, pumped out particles through the dryer filter and uncollected residues in some parts of the dryer.

In Table 4 the calculated values of SMER, MER, and SEC for spray drying process are given. These values are used to define the energy efficient processes and calculated as $(0.33 \pm 0.03 \mathrm{~kg}$ water $/ \mathrm{kWh}-11.07 \pm 0.88 \mathrm{MJ} / \mathrm{kg}$ water) for the whole (WMP) milk powders. When the concentration of $\mathrm{CP}, \mathrm{CNP}$, and GP increased, the increased the feed flow rate decreased the drying time since with the increased solid content amount of water to be evaporated was also decreased $(\mathrm{P}<0.05)$. The results are supported by the study of Calıșkan Koç and Dirim [31] where the researchers reported that when maltodextrin, whey powder and gum Arabic were added to spinach juice, SMER value increased and MER and SEC values decreased due to the increase in total soluble solids content. When the total soluble solid content increased the drying time decreased due to a decrease in water content.

Table 2: The drying time of milk powders and energy consumption of the spray dryer.

\begin{tabular}{|c|c|c|c|c|}
\hline & Concentration [\%] & MPCP & MPCNP & MPGP \\
\hline \multirow{4}{*}{ Drying Time (h) } & 1 & $0.76 \pm 0.06^{\text {cy }}$ & $0.50 \pm 0.03^{\mathrm{cx}}$ & $0.49 \pm 0.05^{\mathrm{cx}}$ \\
\hline & 2 & $0.55 \pm 0.02^{\text {by }}$ & $0.41 \pm 0.06^{b x}$ & $0.34 \pm 0.06^{\mathrm{ax}}$ \\
\hline & 4 & $0.45 \pm 0.09^{a b x y}$ & $0.57 \pm 0.04^{d y}$ & $0.39 \pm 0.06 \mathrm{bx}$ \\
\hline & 8 & $0.38 \pm 0.02^{\mathrm{ax}}$ & $0.31 \pm 0.05$ ax & $0.33 \pm 0.07^{\mathrm{ax}}$ \\
\hline \multirow{4}{*}{ Energy Consumption (kWh) } & 1 & $3.04 \pm 0.19$ cy & $2.01 \pm 0.17^{\mathrm{cx}}$ & $1.94 \pm 0.09^{\mathrm{cx}}$ \\
\hline & 2 & $1.73 \pm 0.01$ by & $1.34 \pm 0.03 \mathrm{ax}$ & $1.33 \pm 0.03^{\mathrm{ax}}$ \\
\hline & 4 & $1.67 \pm 0.12^{\mathrm{bx}}$ & $1.67 \pm 0.09 \mathrm{bx}$ & $1.61 \pm 0.02^{b x}$ \\
\hline & 8 & $1.47 \pm 0.13^{\mathrm{ax}}$ & $1.31 \pm 0.15^{\mathrm{ax}}$ & $1.25 \pm 0.05^{\mathrm{ax}}$ \\
\hline
\end{tabular}

a-d: Show a significant difference between the concentrations (in the same column, $\mathrm{P}<0.05$ ).

$x-z$ : Show a significant difference between the samples (in the same row, $\mathrm{P}<0.05$ ).

Table 3: Total soluble solid content ( $\left.{ }^{\circ} \mathrm{Brix}\right)$ values of milk with CP, CNP, and GP and powder yield (\%).

\begin{tabular}{|c|c|c|c|c|}
\hline & Concentration [\%] & MPCP & MPCNP & MPGP \\
\hline & 1 & $12.0 \pm 0.3^{\text {ay }}$ & $12.0 \pm 0.3^{\text {ay }}$ & $11.5 \pm 0.1^{\mathrm{ax}}$ \\
\hline TSSC & 2 & $12.5 \pm 0.1^{\text {by }}$ & $12.5 \pm 0.3^{\text {by }}$ & $11.8 \pm 0.3^{\mathrm{ax}}$ \\
\hline \multirow{3}{*}{ (orix) } & 4 & $15.0 \pm 0.2^{\text {cy }}$ & $13.0 \pm 0.1^{\mathrm{cx}}$ & $13.0 \pm 0.2^{\mathrm{bx}}$ \\
\hline & 8 & $18.0 \pm 0.3^{\mathrm{dz}}$ & $14.0 \pm 0.0^{\mathrm{dx}}$ & $14.8 \pm 0.2^{\text {cy }}$ \\
\hline & 1 & $55.57 \pm 1.25^{\text {ay }}$ & $45.48 \pm 6.75^{\mathrm{ax}}$ & $42.42 \pm 1.45^{\mathrm{ax}}$ \\
\hline Powder & 2 & $62.55 \pm 2.15^{\mathrm{bz}}$ & $55.12 \pm 2.45^{\text {by }}$ & $41.70 \pm 0.52^{\mathrm{ax}}$ \\
\hline \multirow[t]{2}{*}{ Yield (\%) } & 4 & $67.07 \pm 4.85^{\mathrm{bx}}$ & $61.04 \pm 3.28^{\mathrm{cx}}$ & $63.79 \pm 5.54^{\mathrm{cx}}$ \\
\hline & 8 & $66.63 \pm 7.12^{\mathrm{bz}}$ & $54.23 \pm 4.78^{\text {by }}$ & $46.93 \pm 0.62^{\mathrm{bx}}$ \\
\hline
\end{tabular}

a-d: Show a significant difference between the concentrations (in the same column, $\mathrm{P}<0.05$ ).

$x-z$ : Show a significant difference between the samples (in the same row, $\mathrm{P}<0.05$ ).

Table 4: The calculated values of SMER, MER and SEC for the spray drying process.

\begin{tabular}{|c|c|c|c|c|}
\hline & Concentration [\%] & MPCP & MPCNP & MPGP \\
\hline \multirow{4}{*}{ SMER (kg water/kWh) } & 1 & $0.22 \pm 0.01^{\text {ay }}$ & $0.14 \pm 0.00^{\mathrm{ax}}$ & $0.23 \pm 0.01^{\text {ay }}$ \\
\hline & 2 & $0.26 \pm 0.02^{\mathrm{bx}}$ & $0.26 \pm 0.02^{\mathrm{bx}}$ & $0.33 \pm 0.02^{\text {cy }}$ \\
\hline & 4 & $0.32 \pm 0.03^{d z}$ & $0.25 \pm 0.01^{b x}$ & $0.27 \pm 0.01^{\text {by }}$ \\
\hline & 8 & $0.30 \pm 0.01^{\text {cy }}$ & $0.29 \pm 0.01^{\mathrm{cx}}$ & $0.34 \pm 0.03^{\mathrm{cz}}$ \\
\hline \multirow{4}{*}{$\begin{array}{c}\text { MER } \\
\text { (kg water/h) }\end{array}$} & 1 & $0.90 \pm 0.01^{\text {by }}$ & $0.58 \pm 0.02^{\mathrm{ax}}$ & $0.90 \pm 0.03^{\text {ay }}$ \\
\hline & 2 & $1.06 \pm 0.10^{\text {cy }}$ & $0.79 \pm 0.03^{\mathrm{bx}}$ & $1.31 \pm 0.09 \mathrm{cz}$ \\
\hline & 4 & $0.80 \pm 0.03^{\mathrm{ax}}$ & $0.96 \pm 0.05^{c y}$ & $1.12 \pm 0.06^{\mathrm{bz}}$ \\
\hline & 8 & $1.33 \pm 0.03^{\mathrm{dy}}$ & $1.13 \pm 0.03^{\mathrm{dx}}$ & $1.30 \pm 0.03^{\text {cy }}$ \\
\hline \multirow{3}{*}{ SEC (MJ/kg water) } & 2 & $13.71 \pm 0.60^{\text {by }}$ & $13.78 \pm 0.07$ by & $10.85 \pm 0.09 \mathrm{ax}$ \\
\hline & 4 & $11.15 \pm 0.08^{\mathrm{ax}}$ & $14.33 \pm 0.02^{\text {cy }}$ & $13.31 \pm 1.09$ by \\
\hline & 8 & $11.81 \pm 0.02^{\text {ay }}$ & $12.35 \pm 1.01^{\mathrm{az}}$ & $10.51 \pm 0.85^{\mathrm{ax}}$ \\
\hline
\end{tabular}


Therefore, the addition of drying agents to spinach juice, resulting in an increase of feed flow rate and a decrease of drying time. In this study, shorter drying time related with higher feed concentration caused less energy consumption. So, related with this result an increase in the values of SMER and MER and a decrease of the SEC value was observed depending on the increase in the $\mathrm{CP}, \mathrm{CNP}$, and GP concentration $(\mathrm{P}<0.05)$. In the literature specific energy consumption for the spray drying process was given in the interval of 3-20 MI $/ \mathrm{kg}$ water [32]. Therefore, the calculated SEC values of $10.85-24.87 \mathrm{MJ} / \mathrm{kg}$ water can be considered in the typical range.

In order to select the milk powder for the further agglomeration process, the sensory tests (color, odor, flavor, and overall acceptability) were conducted by semi-trained 10 panelists among students and staffs of the Ege University, Department of Food Engineering, Izmir, Turkey. The concentration below 2\% generally do not affect panelists acceptance, but higher concentration levels (more than $4 \%$ ) significantly decrease it. For this reason, in this study, the CP, CNP, and GP concentration was chosen as $2 \%$ which is acceptable limits for panelists.

Agglomeration yield was defined as the ratio of the amount remained on the screen with $250 \mu \mathrm{m}$ mesh size (which are assumed to be agglomerates) to the total amount of powders. The losses are both unagglomerated powders and some process losses that escaped during fluidized bed operation or that took place in transfer and cleaning operations. The agglomeration yield was found to be as $69.41 \pm 0.10$ for AWMP, $63.00 \pm 9.16 \%$ for ACMP, $67.51 \pm 0.33 \%$ for ACNMP, and $50.27 \pm 5.70 \%$ for AGMP. The losses during agglomeration process may be due to being deposited on the wall, pumping out the fine particles through the filter, an insufficient amount of binder, insufficient mixing with the binder, lower drying time and uncollected residues etc. In a study where soy protein isolate was obtained by pulsed fluidized bed an agglomeration, a similar process yield was determined as $67 \%$ [33]. The air velocity was selected to be $0.51-0.67 \mathrm{~m} / \mathrm{s}$, the feeding rate of the carboxymethyl cellulose solution as the binding solution $1.2-2 \mathrm{ml} / \mathrm{min}$, the air temperature $60-80{ }^{\circ} \mathrm{C}$, atomizing air pressure, air pulsation frequency and the processing time were $0.5 \mathrm{bar}, 600 \mathrm{rpm}$, and $30 \mathrm{~min}$ [33].

\subsection{Moisture content, water activity, and color values of milk powders and agglomerates}

The addition of the aroma compounds into the milk changed the total soluble solid content of the milk. As it is well known from the literature that, the feed composition and concentration have significant effect on the residual moisture content of the final powders since it directly affects feed flow rate which is important for contact time of the sample and hot air, and as a result it affect the heat and mass transfer. The results obtained from the characterization of the milk powders containing $\mathrm{CP}$, CNP, and GP are shown in Table 5. The moisture content and water activity values of the WMP were found to be as $3.12 \pm 0.14 \%$ and $0.277 \pm 0.02$, respectively. Pugliese et al. [34] also reported that the moisture content and water activity values of the whole milk powders ranged between $2.64-4.00 \%$ and $0.272-0.329$, respectively. The water activity values of WMP were reported to be as 0.360 [35] and 0.230 [36] which are also consistent with the results of this study. Lower moisture content and water activity values were obtained for MPCP, MPCNP and MPGP compared to the WMP which is due to the higher TSSC of the milk. MPCP has higher TSSC compared to the other samples, as a result, lower moisture content values were obtained for the MPCP. The moisture content values of MPCP, MPCNP, and MPGP showed that when the powders are mixed with milk their water binding capacities are affected. According to Table 5, it can be said that increasing the TSSC of the feed generally causes available for evaporation and results in significantly lower moisture content values $(\mathrm{P}<0.05)$. Milk powders are supposed to be stored for long periods of time [37],[38]. For this reason, it is crucial to store the milk powders at the correct temperature and $\mathrm{a}_{\mathrm{w}}$ which is below the glass transition temperature $\left(\mathrm{T}_{\mathrm{g}}=309 \mathrm{~K}\right)$ of lactose. For the prevention of crystallization of the amorphous lactose and induced water migration which can deteriorate the stability of powders during storage temperature and water, activity should be controlled. The water activity values ranged between 0.157-0.201 for MPCP, 0.178-0.247 for MPCNP and 0.179-0.263 for MPGP which are in the acceptable limits for long-term storage $(a w<0.3,[39])$. The differences in the chemical compositions (sugar, fiber content etc.) or the behavior in the milk (sinking, sedimentation, suspension, gel structure etc.) of $\mathrm{CP}, \mathrm{CNP}$, and GP may be the reason for the different moisture content and water activity values of the obtained milk powder. The results showed that when the concentration of the samples increases, first the water activity values increase but above $4 \%$ decreases again.

The moisture content and water activity values of the agglomerated milk powders with $\mathrm{CP}, \mathrm{CNP}$, and GP are given in Table 6.

Table 5: The moisture content and water activity values of spray-dried milk powders with CP, CNP and GP.

\begin{tabular}{|c|c|c|c|c|}
\hline Analysis & Concentration [\%] & MPCP & MPCNP & MPGP \\
\hline \multirow{4}{*}{ Moisture Content $(\%, w b)$} & 1 & $1.66 \pm 0.18^{\mathrm{bx}}$ & $2.35 \pm 0.11^{\text {by }}$ & $1.40 \pm 0.37^{\mathrm{abx}}$ \\
\hline & 2 & $1.95 \pm 0.22^{\text {by }}$ & $1.45 \pm 0.21^{\text {ay }}$ & $1.15 \pm 0.07^{\mathrm{ax}}$ \\
\hline & 4 & $1.14 \pm 0.03^{\mathrm{ax}}$ & $1.40 \pm 0.28$ ay & $1.69 \pm 0.09 \mathrm{bz}$ \\
\hline & 8 & $1.09 \pm 0.08^{\mathrm{ax}}$ & $2.23 \pm 0.20^{\mathrm{bz}}$ & $1.23 \pm 0.08^{\text {ay }}$ \\
\hline \multirow{4}{*}{ Water Activity } & 1 & $0.176 \pm 0.03^{\mathrm{bx}}$ & $0.178 \pm 0.03^{\mathrm{ax}}$ & $0.179 \pm 0.00^{\text {ax }}$ \\
\hline & 2 & $0.194 \pm 0.02^{\mathrm{cx}}$ & $0.201 \pm 0.02^{\text {by }}$ & $0.217 \pm 0.02^{\mathrm{bz}}$ \\
\hline & 4 & $0.201 \pm 0.01^{\mathrm{dx}}$ & $0.247 \pm 0.03^{c y}$ & $0.263 \pm 0.01^{\mathrm{dz}}$ \\
\hline & 8 & $0.157 \pm 0.03^{\mathrm{ax}}$ & $0.200 \pm 0.02^{\text {by }}$ & $0.242 \pm 0.01^{\mathrm{cz}}$ \\
\hline
\end{tabular}

a-d: Show a significant difference between the concentrations (in the same column, $\mathrm{P}<0.05$ ).

$x-z$ : Show a significant difference between the samples (in the same row, $\mathrm{P}<0.05$ ).

Table 6: The moisture content and water activity values of agglomerated milk powders containing CP, CNP, and GP.

\begin{tabular}{ccccc}
\hline Analysis & AWMP & ACMP & ACNMP & AGMP \\
\hline Moisture Content $(\%, w b)$ & $3.45 \pm 0.27^{\mathrm{a}}$ & $3.93 \pm 0.18^{\mathrm{b}}$ & $4.60 \pm 0.49^{\mathrm{c}}$ & $3.94 \pm 0.29^{\mathrm{b}}$ \\
Water Activity & $0.171 \pm 0.31^{\mathrm{b}}$ & $0.137 \pm 0.00^{\mathrm{a}}$ & $0.232 \pm 0.01^{\mathrm{c}}$ & $0.257 \pm 0.00^{\mathrm{c}}$ \\
\hline
\end{tabular}

a-c: Show a significant difference between the samples (in the same row, $\mathrm{P}<0.05$ ). 
The highest moisture content value was observed for the agglomerated milk powder with cinnamon powder (ACMP) while the lowest value was observed for the agglomerated whole milk powder (AWMP). The moisture content values of agglomerates were found to be significantly higher compared to the corresponding milk powders $(\mathrm{P}<0.05)$. Similarly, for the agglomeration of acacia powder modified starch and maltodextrin, the same result was observed [5]. In wet agglomeration process, distilled water was used as a binder which is responsible for binding the particles by liquid bridges. During the agglomeration process, the penetration of liquid into particle packages and drying processes take place simultaneously. Besides the additional amount of water to the powders, the crust formation during drying may be the reason for the higher moisture content of the agglomerates compared to the related powders.

The water activity values of the agglomerates ranged between 0.171 and 0.257 which are also within the acceptable limits for safety storage $(a w<0.3,[39])$. The water activity values of agglomerated milk powder with cinnamon (ACNMP) and ginger (AGMP) powders were found to be significantly higher than MPCNP and MPGP $(\mathrm{P}<0.05)$. It may be due to the hygroscopic structure of cinnamon and ginger powders.

The color values of the milk powders containing carob, cinnamon, and ginger powders are shown in Figure 2.

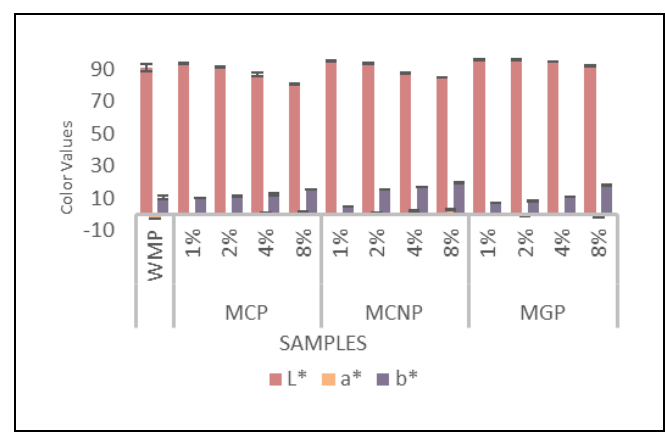

Figure 1: The color values of milk powders.

The brightness value of WMP were found to be as 90.98. Similar findings were reported by Pugliese et al. [34] $\left(\mathrm{L}^{*}=96.06-96.49\right.$, $\mathrm{a}^{*}=(-) 1.78-(-) 1.43, \mathrm{~b}^{*}=13.70-14.59$ for whole milk powder. The oxidation or browning reaction may be prevented during the spray drying due to the antioxidant activity of the CNP and GP. Ginger and cinnamon powders have bright color compared to the carob powder. For this reason, higher brightness values were obtained for MPCNP and MPGP compared to the MPCP. According to the results, increasing the TSSC of milk resulted in a significant decrease in the brightness values and a significant increase in the $b^{*}$ values $(P<0.05)$. The $a^{*}$ values of the milk powders significantly increased depending on the increasing amount of the CP and CNP $(\mathrm{P}<0.05)$. However, $\mathrm{a}^{*}$ value of the MPGP decreased depending on the increasing amount of the GP due to low $a^{*}$ value $(-0.76 \pm 0.46)$ of the GP. Similarly, the results of the color values of CP, CNP and GP, the lower $\mathrm{L}^{*}$ values were observed from MPCP, while lower $a^{*}$ and $b^{*}$ values were observed from MPGP. The color values of the agglomerated milk powders with CP, CNP and GP are shown in Figure 3.

Similar to the color values of the milk powders, significantly higher $\mathrm{L}^{*}$ value was observed for AMPCP $(\mathrm{P}<0.05)$. The lower brightness values were obtained for the agglomerated milk powders compared to the corresponding milk powder due to the heat effect. During the agglomeration process, the heat may cause some browning reactions. The $a^{*}$ and $b^{*}$ values of the agglomerated milk powders were found to be higher than corresponding milk powders. The total color change values of agglomerated milk powders with respect to corresponding milk powders were calculated to be as 9.91 for AWMP, 10.95 for MPCNP, 12.70 for AMPCNP, and 11.71 for AMPGP, respectively.

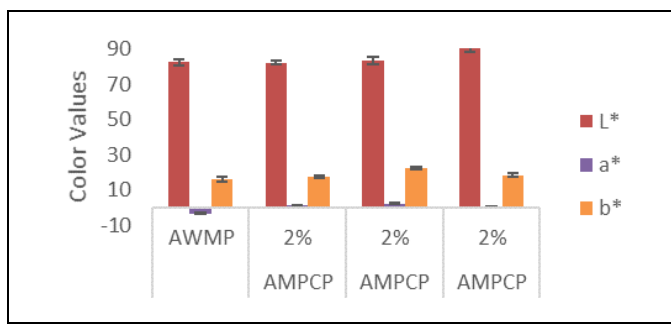

Figure 3: The color values of agglomerated milk powders.

\subsection{Powder properties of milk powders and agglomerates}

The powder properties of the MPCP, MPCNP, and MPGP are given in Table 7 . The solubility time of the WMP was found to be as $350.0 \pm 20.5 \mathrm{~s}$. According to Table 7, it can be said that the addition of an increasing amount of CP and GP generally resulted in a significant decrease in the solubility times of the powders $(\mathrm{P}<0.05)$. On the other hand, the solubility times of the MPCNP decreased with the increase of the CNP concentration up to $4 \%$ and then increased again.

As can be seen from Table 8, the agglomeration process significantly decreased the solubility times of the milk powders $(\mathrm{P}<0.05)$. Buffo et al. [5] reported that agglomerates dissolve or disperse more readily in liquids than the spray-dried powder owing to the pore system of the agglomerates. In addition, Schubert [40] reported that the powder properties such as flowability, wettability, and dispersibility depend on the particle size and fine particles have a tendency to form lumps due to high surface tension which is related to the higher wettability and solubility times. In this study, the higher moisture content, porous structure, and the average particle size of the agglomerates based on screen analysis resulted in a significant decrease in the solubility times of the agglomerates compared to the milk powders $(\mathrm{P}<0.05)$.

The dispersibility value of the WMP was found to be as $57.00 \pm$ $1.28 \%$. The dispersibility values of MPCP, MPCNP, and MPGP are $35.42 \pm 1.23-59.12 \pm 2.42 \%, 30.66 \pm 2.32-47.37 \pm 0.27 \%$, and $33.30 \pm 1.52-38.56 \pm 2.74 \%$, respectively.

For the considerations in the economic, commercial and functional properties, the bulk density of milk powders constitutes an important property. High bulk density value is important for saving transportation and packaging material costs by reducing the container volume. Tapped density is an important parameter for the powder behavior during compaction [30],[41]. The bulk and tapped density values of the WMP were found to be as $216.92 \pm 8.79 \mathrm{~kg} / \mathrm{m}^{3}$ and $442.50 \pm 11.59 \mathrm{~kg} / \mathrm{m}^{3}$. Pugliese et al. [34] reported that the bulk and tapped density values of the spray-dried four whole and seven skim milk powders varied between $396-480 \mathrm{~kg} / \mathrm{m}^{3}$ and $553-662 \mathrm{~kg} / \mathrm{m}^{3}$ and $407-666 \mathrm{~kg} / \mathrm{m}^{3}$ and $578-87 \mathrm{~kg} / \mathrm{m}^{3}$, respectively. The different density values may be due to the different process conditions (inlet/outlet temperature, feed flow rate, atomization pressure etc.) which are effective on the physical and powder properties. 
Table 7: The powder properties of the milk powders containing CP, CNP, and GP.

\begin{tabular}{|c|c|c|c|c|}
\hline Analysis & Concentration [\%] & MPCP & MPCNP & MPGP \\
\hline \multirow{4}{*}{ Solubility Time (s) } & 1 & $519.5 \pm 13.4^{\mathrm{cz}}$ & $433.5 \pm 30.4^{\mathrm{cy}}$ & $254.5 \pm 15.4^{\mathrm{cx}}$ \\
\hline & 2 & $194.0 \pm 12.0^{\mathrm{bx}}$ & $240.0 \pm 15.0^{\text {ay }}$ & $244.5 \pm 27.3^{c y}$ \\
\hline & 4 & $182.0 \pm 10.2^{\mathrm{bx}}$ & $245.0 \pm 9.7^{\text {ay }}$ & $163.5 \pm 19.1^{\mathrm{bx}}$ \\
\hline & 8 & $111.5 \pm 7.8^{\mathrm{ax}}$ & $362.5 \pm 34.7^{\text {by }}$ & $120.5 \pm 8.5^{\mathrm{ax}}$ \\
\hline \multirow{4}{*}{ Bulk Density $\left(\mathrm{kg} / \mathrm{m}^{3}\right)$} & 1 & $166.85 \pm 5.56^{\text {ax }}$ & $182.36 \pm 9.85^{\text {ay }}$ & $259.21 \pm 3.95^{\mathrm{dz}}$ \\
\hline & 2 & $223.47 \pm 6.08^{\mathrm{cz}}$ & $183.33 \pm 16.67^{\mathrm{ax}}$ & $208.33 \pm 0.00^{\text {by }}$ \\
\hline & 4 & $196.15 \pm 3.85^{\text {by }}$ & $174.24 \pm 7.58^{\mathrm{ax}}$ & $236.75 \pm 14.53^{\mathrm{cz}}$ \\
\hline & 8 & $250.63 \pm 12.53^{\text {dy }}$ & $202.00 \pm 2.00^{\mathrm{bx}}$ & $200.00 \pm 0.00^{\mathrm{ax}}$ \\
\hline \multirow{4}{*}{ Tapped Density $\left(\mathrm{kg} / \mathrm{m}^{3}\right)$} & 1 & $392.31 \pm 7.69^{\mathrm{bz}}$ & $357.14 \pm 0.00^{\text {cy }}$ & $339.66 \pm 5.17^{\mathrm{ax}}$ \\
\hline & 2 & $373.67 \pm 11.95^{\text {ay }}$ & $345.24 \pm 11.90^{\mathrm{bx}}$ & $384.62 \pm 0.00^{\mathrm{cy}}$ \\
\hline & 4 & $428.65 \pm 7.69^{\mathrm{bz}}$ & $333.33 \pm 0.00^{\mathrm{ax}}$ & $353.57 \pm 3.57^{\text {by }}$ \\
\hline & 8 & $500.23 \pm 0.00^{\mathrm{cz}}$ & $368.17 \pm 16.45^{\mathrm{dx}}$ & $400.00 \pm 0.00^{\mathrm{dy}}$ \\
\hline \multirow{8}{*}{ Flowability (CI) } & 1 & $57.48 \pm 0.58^{\mathrm{cz}}$ & $48.94 \pm 2.79^{\mathrm{ay}}$ & $23.68 \pm 0.01^{\mathrm{ax}}$ \\
\hline & & (Very Bad) & (Very Bad) & (Fair) \\
\hline & 2 & $45.42 \pm 3.56^{\mathrm{ax}}$ & $46.90 \pm 3.00^{\text {ay }}$ & $45.83 \pm 0.00^{c y}$ \\
\hline & & (Very Bad) & (Very Bad) & (Very Bad) \\
\hline & 4 & $50.00 \pm 0.00^{\text {by }}$ & $47.73 \pm 2.27^{\text {ay }}$ & $33.04 \pm 4.78^{\mathrm{bx}}$ \\
\hline & & (Very Bad) & (Very Bad) & (Fair) \\
\hline & 8 & $49.87 \pm 2.51^{\text {by }}$ & $45.13 \pm 3.00^{\mathrm{ax}}$ & $50.00 \pm 0.00^{\mathrm{dy}}$ \\
\hline & & (Very Bad) & (Very Bad) & (Very Bad) \\
\hline \multirow{8}{*}{ Cohesiveness (HR) } & 1 & $2.35 \pm 0.03^{\mathrm{dz}}$ & $1.96 \pm 0.12^{c y}$ & $1.31 \pm 0.01^{\mathrm{ax}}$ \\
\hline & & (High) & (High) & (Intermediate) \\
\hline & 2 & $1.86 \pm 0.10^{\mathrm{ax}}$ & $1.88 \pm 0.11^{\text {by }}$ & $1.85 \pm 0.00^{\mathrm{cy}}$ \\
\hline & & (High) & (High) & (High) \\
\hline & 4 & $1.99 \pm 0.00^{\text {by }}$ & $1.91 \pm 0.08^{\text {by }}$ & $1.49 \pm 0.11^{b x}$ \\
\hline & & (High) & (High) & (High) \\
\hline & 8 & $2.00 \pm 0.01^{\mathrm{cy}}$ & $1.82 \pm 0.10^{\mathrm{ax}}$ & $2.00 \pm 0.00^{\mathrm{dy}}$ \\
\hline & & (High) & (High) & (High) \\
\hline \multirow{4}{*}{ Hygroscopicity (\%) } & 1 & $10.08 \pm 0.01^{\mathrm{az}}$ & $8.43 \pm 0.05^{\text {ay }}$ & $8.03 \pm 0.23^{\mathrm{ax}}$ \\
\hline & 2 & $10.72 \pm 0.01^{\text {by }}$ & $8.13 \pm 0.01^{\mathrm{ax}}$ & $8.09 \pm 0.32^{\mathrm{ax}}$ \\
\hline & 4 & $10.05 \pm 0.07^{\mathrm{az}}$ & $8.97 \pm 0.06^{\text {by }}$ & $7.16 \pm 0.85^{\mathrm{ax}}$ \\
\hline & 8 & $15.17 \pm 0.10^{\mathrm{cz}}$ & $8.14 \pm 0.41^{\mathrm{ax}}$ & $8.91 \pm 0.14^{\text {by }}$ \\
\hline
\end{tabular}

a-d : Show a significant difference between the concentrations (in the same column, $\mathrm{P}<0.05$ ). $\mathrm{x}-\mathrm{z}$ : Show a significant difference between the samples (in the same row, $\mathrm{P}<0.05$ ).

Table 8: The powder properties of the milk agglomerates containing CP, CNP, and GP.

\begin{tabular}{|c|c|c|c|c|}
\hline Analysis & AWMP & ACMP & ACNMP & AGMP \\
\hline Ds $(\mathrm{mm})$ & $1.9707 \pm 0.31^{\mathrm{c}}$ & $0.8359 \pm 0.24^{\mathrm{a}}$ & $1.0091 \pm 0.35^{\mathrm{ab}}$ & $0.2450 \pm 0.13^{b}$ \\
\hline Solubility Time (s) & $9 \pm 1.41^{\mathrm{a}}$ & $25 \pm 7.07^{b}$ & $51.5 \pm 2.12^{\mathrm{c}}$ & $47.5 \pm 3.53^{c}$ \\
\hline Bulk Density $\left(\mathrm{kg} / \mathrm{m}^{3}\right)$ & $278.7 \pm 0.01^{\mathrm{a}}$ & $328.3 \pm 0.02^{\mathrm{a}}$ & $278.5 \pm 0.02^{a}$ & $275 \pm 0.00^{\mathrm{a}}$ \\
\hline Tapped Density $\left(\mathrm{kg} / \mathrm{m}^{3}\right)$ & $301.5 \pm 0.00^{a}$ & $485 \pm 0.04^{c}$ & $379.5 \pm 0.01^{b}$ & $400 \pm 0.00^{b}$ \\
\hline Carr Index & $7.9365 \pm 4.48^{\mathrm{b}}($ Very good $)$ & $\begin{array}{l}32.2917 \pm 1.47^{a} \\
\text { (Intermediate) }\end{array}$ & $\begin{array}{l}26.7647 \pm 4.57^{b} \\
\text { (Intermediate) }\end{array}$ & $\begin{array}{c}31.2500 \pm 0^{\mathrm{b}} \\
\text { (Intermediate) }\end{array}$ \\
\hline Hausner Ratio & $\begin{array}{l}1.0875 \pm 0.05^{\mathrm{a}} \\
\text { (Low) }\end{array}$ & $\begin{array}{c}1.4773 \pm 0.03^{\text {a }} \\
\text { (High) }\end{array}$ & $\begin{array}{c}1.5629 \pm 0.36^{\mathrm{a}} \\
\text { (High) }\end{array}$ & $\begin{array}{c}1.4545 \pm 0^{\mathrm{a}} \\
\text { (High) }\end{array}$ \\
\hline
\end{tabular}

a-d: Show a significant difference between the samples (in the same row, $\mathrm{P}<0.05$ ).

The average bulk density value MPGP (226.07 kg/m³) was found to be higher compared to the WMP and other powders. According to the results, it can be said that the addition of $\mathrm{CP}$,
CNP and GP to the milk resulted in significantly lower tapped density values $(\mathrm{P}<0.05)$. 
The bulk and tapped density values of the agglomerated milk powders were significantly higher compared to the corresponding powders $(\mathrm{P}<0.05$, Table 8). Although, the general tendency is to obtain lower bulk densities, Similar findings were also obtained by Jinapong et al. [21]. Jinapong et al. [21] reported that the bulk and tapped density values of the spray-dried $\left(180 \pm 1 / 80 \pm 1{ }^{\circ} \mathrm{C}\right.$ inlet/outlet temperatures, 4 bar air pressure) soymilk powder and agglomerated soymilk powders (in top-sprayed fluidized bed granulator, 1.5 bar nozzle pressure, $200 \mathrm{~g}$ powder: $200 \mathrm{ml}$ water, powder was dried for $15 \mathrm{~min}$ at a temperature of $50{ }^{\circ} \mathrm{C}$ ) were found to be as $0.21 \pm 0.00$ and $0.35 \pm 0.00 \mathrm{~g} / \mathrm{cm}^{3}$ and $0.31 \pm 0.00$ and $0.46 \pm 0.00 \mathrm{~g} / \mathrm{cm}^{3}$, respectively. The researchers declared that the higher particle size of the agglomerates resulted in the less cohesive and more free-flowing powder which is responsible for higher bulk density, as the interparticle forces between particles become weaker, therefore powder should pack in a denser condition [21]. In addition, Buffo et al. [5] reported that the moisture contents of agglomerated spray-dried encapsulated flavor powders increased 2 times more than those of the powders and the high moisture obtained as a result of more compact structures and as a result increased density. Benkovic et al. [42] reported that the use of water helps to obtain the formation of liquid bridges between the particles, resulting in more porous structures as well as higher tapped density in the wet agglomeration process. Similarly, in this study, the moisture content values of the agglomerated milk powders were found to be significantly higher than corresponding powders $(\mathrm{P}<0.05)$. The higher moisture content, particle size, and porosity of the agglomerates and the entrapped air in the particles can be the reason for the higher bulk and tapped density values of the agglomerates.

The $\mathrm{CI}$ and HR values of the WMP were found to be as $50.89 \pm 3.27$ (Very Bad) and $2.05 \pm 0.14$ (High). Pugliese et al. [34] reported that the flowability (CI) and cohesiveness (HR) values of the spray-dried four whole and seven skim milk powders ranged between 27.50-29.00 and 1.38-1.41 and 23.50-29.50 and 1.31-1.42, respectively. The flowability values, which are evaluated on the basis of these indices, have changed from fair to poor. The differences between these values may be due to the different drying conditions and milk composition. It was stated by Kim et al. [43] that, the surface composition of the milk powders contains lactose, protein and a small amount of fat. Especially due to high-fat content on the surface at high temperatures adhesive, rubbery, and viscous liquid is observed due to fat melting. Fitzpatrick et al. [44] also reported that many dairy powders are cohesive. Although the flow properties are not at the desired level in the industry there are several foodgrade additives (maltodextrin, gum Arabic etc.) which improve the flow properties.

The CI and HR values of the agglomerated milk powders are given in Table 8. Due to the application of agglomeration size enlargement takes place and this leads to an improvement in flow characteristics. Similar results were also obtained for agglomerated soymilk powders [21]. Jinapog et al. [21] reported that the reason for the poorer flow characteristics is related with particle size, where the mean particle size and existence of different particle sizes are important and especially the fine particles are important. The higher size of the agglomerated milk powders may be the reason for the better flow characteristics compared to the milk powders. Although the flowability and cohesiveness of ACMP, ACNMP, and AGMP are not yet ideal, the agglomerates show improved handling properties compared to milk powders.

The hygroscopicity (\%) value of the WMP was found to be as and $10.17 \pm 0.03 \%$. The lower hygroscopicity values were obtained for MPGP which has higher water activity value. The hygroscopicity values of agglomerated milk powders were found to be lower compared to the corresponding milk powder (Table 8). The higher moisture content of the agglomerates may be the reason. In their study, Santana et al. [45] and Ferrari et al. [46] explained that the fact that the high-water concentration difference between the product and air where product exists leads to high hygroscopicity are inversely proportional with the moisture content of the product.

Agglomeration process has been commonly used to improve functional properties of powder products where they form larger agglomerates. In this study, the volume means diameter $\left(D_{s}\right)$ of the agglomerates ranged between $0.245 \mathrm{~mm}$ (AGMP) and $1.9707 \mathrm{~mm}$ (AWMP) while the sizes of the milk powders were found to be less than $212 \mu \mathrm{m}$ (Table 8). In the literature, the spray drying of an aqueous emulsion containing vegetable oil, maltodextrin and acacia gum resulted in small particles $(<50 \mu \mathrm{m})$. Particle sizes were found to reaching $150 \mu \mathrm{m}$ by agglomeration in a fluidized bed made by spraying water onto powder products [47].

\section{Conclusion}

In this study milk powders containing carob, cinnamon and ginger were successfully obtained. Results showed that the moisture contents and water activity values of all powders and agglomerates were within acceptable limits (moisture content $<10 \%, a w<0.3$ ) for safe storage of products. Comparatively better results were obtained for MPGP for solubility, flowability, cohesiveness, and hygroscopicity. The physical and reconstitution properties of the milk powders are improved by the agglomeration process with water using a fluidized bed dryer. The solubility times of milk powders were significantly decreased by the agglomeration process $(97.42 \%$ for WMP, $87.11 \%$ for MPCP, $78.54 \%$ for MPCNP and $80.57 \%$ for MPGP). Higher particle size of the agglomerated milk powders (0.2450-1.9707 $\mathrm{mm})$ resulted in the less cohesive and more free-flowing (intermediate-very good levels) product compared to the corresponding powder which is responsible for higher bulk density (increase of $28.51 \%$ for WMP, $47.48 \%$ for MPCP, $51.92 \%$ for MPCNP and $32.00 \%$ for MPGP). The changes in the powder properties of milk powder and agglomerates during storage can be studied in the further studies.

\section{References}

[1] Thomas MEC, Scher J, Desobry-Banon S, Desobry S. "Milk powders ageing, effect on physical and functional properties". Critical Reviews in Food Science and Nutrition, 44(5), 297-322, 2004.

[2] Sharma A, Jana AH, Chavan RS. "Functionality of milk powders and milk-based powders for end use applications-a review". Comprehensive Reviews in Food Science and Food Safety, 11(5), 518-528,2012.

[3] Food and Agricultural Organisation of the United Nations (FAO). "Food Outlook, Biannual Report on Global Food Markets". USA, 48-51, 2016. 
[4] Bayram ÖA, Bayram M, Tekin AR. "Spray drying of sumac flavor using sodium chloride, sucrose, glucose, and starch as carriers". Journal of Food Engineering, 69(2), 253-260, 2005.

[5] Buffo RA, Probst K, Zehentbauer G, Luo Z, Reineccius GA. "Effects of agglomeration on the properties of spray-dried encapsulated flavours". Flavour and Fragrance Journal, 17(4), 292-299, 2002.

[6] Caric' M. Milk Powders, Types and Manufacture and Physical and Functional Properties of Milk Powders. Editors: Roginski H, Fuquay JW, Fox PF. Encyclopedia of Dairy Sciences, 1869-1880, New York, USA, Academic Press, 2003.

[7] Hemati M, Cherif R, Saleh K, Pont V. "Fluidized bed coating and granulation, influence of process-related variables and physicochemical properties on the growth kinetics". Powder Technology, 130(1-3), 18-34,2003.

[8] Burggraeve A, Monteyne T, Vervaet C, Remon JP, Beer TD. "Process analytical tools for monitoring, understanding, and control of pharmaceutical fluidized bed granulation, a review". The European Journal of Pharmaceutics and Biopharmaceutics, 83(1), 2-15,2013.

[9] Kleinebudde P. "Roll compaction/dry granulation, pharmaceutical applications". European Journal of Pharmaceutics and Biopharmaceutics, 58(2), 317-326, 2004.

[10] Bindhumadhavan G, Seville JPK, Adams MJ, Greenwood RW, Fitzpatrick S. "Roll compaction of a pharmaceutical excipient, experimental validation of rolling theory for granular solids". Chemical Engineering Science, 60(14), 3891-3897, 2005.

[11] Gereg GW, Cappola ML. "Roller compaction feasibility for new drug candidates Laboratory to production scale". Pharmaceutical Technolgy, 26, 14-23, 2002.

[12] Kumazawa S, Tanıguchi M, Suzuki Y, Shımura M, Kwon M, Nakayama T. "Antioxidant activity of polyphenols in carob pods". Journal of Agricultural and Food Chemistry, 50(2), 373-377,2002.

[13] Dakia PA, Wathelet B, Paquot M. "Isolation and chemical evaluation of carob (Ceratonia siliqua L.) seed germ". Food Chemistry, 102(4), 1368-1374,2007.

[14] Feillet P, Roulland TM. "Caroubin, a gluten-like protein isolate from carob bean germ". Cereal Chemistry, 75(4), 488-492, 1998.

[15] Murcia MA, Egea I, Romojaro F, Parras P, Jimenez AM, Martinez-Tome M. "Antioxidant evaluation in dessert spices compared with common food additives. Influence of irradiation procedure". Journal of Agricultural and Food Chemistry, 52(7), 1872-1881, 2004.

[16] Singletary K. "Ginger an overview of health benefits". Nutrition Today, 45(4), 171-183, 2010.

[17] Chua KJ, Chou SK, Ho JC, Hawlader, MNA. "Heat pump drying, recent developments and future trends". Drying Technology, 20(8), 1580-1600,2002.

[18] Jindarat W, Rattanadecho P, Vongpradubchai S. "Analysis of energy consumption in microwave and convective drying process of multi-layered porous material inside a rectangular wave guide". Experimental Thermal and Fluid Science, 35(4),728-737, 2011.

[19] AOAC. Official Methods of Analysis, 17th ed. Gaithersburg, USA, Association of Official Analytical Chemists, 2000.
[20] Goula AM, Adamopoulos KG. "Effect of maltodextrin addition during spray drying of tomato pulp in dehumidified air, II. Powder properties". Drying Technology, 26(6), 726-737, 2008.

[21] Jinapong N, Suphantharika M, Jamnong P. "Production of instant soymilk powders by ultrafiltration, spray drying and fluidized bed agglomeration". Journal of Food Engineering, 84(2), 194-205,2008.

[22] Carr RL. "Evaluating flow properties of solids". Chemical Engineering, 72, 163-168,1965.

[23] Hausner HH. "Friction conditions in a mass of metal powder". International Journal of Powder Metall, 3, 7-13, 1967.

[24] Cai YZ, Corke H. "Production and properties of spray-dried amaranthus $\beta$-cyanin pigments". Journal of Food Science, 65(7), 1248-1252,2000.

[25] Reddy RS, Ramachandraa CT, Hiregoudar S, Nidoni U, Ramb J, Kammar M. "Influence of processing conditions on functional and reconstitution properties of milk powder made from Osmanabadi goat milk by spray drying". Small Ruminant Research, 119(1-3), 130-137,2014.

[26] Yousif AK, Alghzawi HM. "Processing and characterization of carob powder". Food Chemistry, 69(3), 283-287, 2000.

[27] Barnwal P, Singh K, Mohite A. "Determination of thermal properties of the cryoground cinnamon powder". Journal of Spices and Aromatic Crops, 23(2), 262-267, 2014.

[28] Sangwan A, Kawatra A, Sehgal S. "Nutritional composition of ginger powder prepared using various drying methods". Journal of Food Science and Technology, 51(9), 2260-2262, 2014.

[29] Bhandari BR, Datta N, Crooks R, Howes T, Rigby S. "A semiempirical approach to optimise the quantity of drying aids required to spray dry sugar rich foods". Drying Technology, 15(10), 2509-2525,1997.

[30] Fang Z, Bhandari B. "Effect of spray drying and storage on the stability of bayberry polyphenols". Food Chemistry, 129(3), 1139-1147, 2011.

[31] Çalıșkan Koç G, Dirim, SN. "Spray dried spinach juice, powder properties". Journal of Food Measurement and Characterization, 12(3), 1654-1668, 2018.

[32] Baker CGJ, McKenzie KA. "Energy consumption of industrial spray dryers". Drying Technology, 23, 365-386, 2005.

[33] Machado VG, Hirata TAM, Menegalli FC. "Agglomeration of soy protein isolate in a pulsed fluidized bed, experimental study and process optimization". Powder Technology, 254, 248-255, 2014.

[34] Pugliese A, Cabassi G, Chiavaro E, Paciulli M, Carini E, Mucchetti, G. "Physical characterization of whole and skim dried milk powders". Journal of Food Science and Technology, 54(11), 3433-3442,2017.

[35] Szulc K, Nazarko J, Ostrowska-Ligeza E, Lenart A. "Effect of fat replacement on flow and thermal properties of dairy powders". LWT-Food Science and Technology, 68, 653-658, 2016.

[36] Thomsen MK, Jespersen L, Sjøstrøm K, Risbo J, Skibsted LH. "Water activity-temperature state diagram of amorphous lactose". Journal of Agricultural and Food Chemistry, 53(23), 9182-9185,2005.

[37] Pugliese A, Paciulli M, Chiavaro E, Mucchetti G. "Characterization of commercial dried milk and some of its derivatives by differential scanning calorimetry". Journal of Thermal Analysis and Calorimetry, 123(3), 2583-2590, 2016. 
[38] Kim EHJ, Chen XD, Pearce D. "Surface composition of industrial spray-dried milk powders. 3 . Changes in the surface composition during long-term storage". Journal of Food Engineering, 94(2), 182-191, 2009.

[39] Quek SY, Chok NK, Swedlund P. "The physicochemical properties of spray-dried watermelon powders". Chemical Engineering and Process Intensification, 46(5), 386-392, 2007.

[40] Schubert H. "Food particle technology. Part I, properties of particles and particulate food systems". Journal of Food Engineering, 6(1), 1-32, 1987.

[41] Barbosa-Cánovas GV, Juliano P. Physical and Chemical Properties of Food Powders. Editor: C. Onwulata, Encapsulated and Powdered Foods. 39-71, Boca Raton, Florida, USA, Taylor \& Francis, 2005.

[42] Benkovic M, Tusek AJ, Belscak-Cvitanovic A, Lenart A, Domian E, Komes D, Bauman I. "Artificial neural network modelling of changes in physical and chemical properties of cocoa powder mixtures during agglomeration". LWT-Food Science and Technology, 64(1), 140-148, 2015.
[43] Kim EHJ, Chena XD, Pearce D. "Effect of surface composition on the flowability of industrial spray-dried dairy powders". Colloids and Surfaces B, Biointerfaces, 46(3), 182-187,2005.

[44] Fitzpatrick JJ, Barry K, Cerqueira PSM, Iqbal T, O'Neill J, Roos YH. "Effect of composition and storage conditions on the flowability of dairy powders". International Dairy Journal, 17(4), 383-392, 2007.

[45] Santana AA, Oliveira RA, Pinedo AA, Kurozawa LE, Park, KJ. "Microencapsulation of babassu coconut milk". LWT-Food Science and Technology, 33(4), 737-744, 2013.

[46] Ferrari CC, Germer, SPM, De Aguirre JM. "Effects of spray-drying conditions on the physicochemical properties of blackberry powder". Drying Technology, 30(2), 154-163, 2011.

[47] Fuchs M, Turchiuli C, Bohin M, Cuvelier ME, Ordonnaud C, Peyrat-Maillard MN, Dumoulin E. "Encapsulation of oil in powder using spray drying and fluidized bed agglomeration". Journal of Food Engineering, 75(1), 27-35, 2006. 